\title{
An Env-like protein encoded by a Drosophila retroelement: evidence that gypsy is an infectious retrovirus
}

\author{
Sun U. Song, ${ }^{1}$ Tatiana Gerasimova, ${ }^{1}$ Maryellen Kurkulos, ${ }^{1,2}$ Jef D. Boeke, ${ }^{2,3}$ and Victor G. Corces ${ }^{1,3}$ \\ ${ }^{1}$ Department of Biology, The Johns Hopkins University, Baltimore, Maryland 21218 USA; ${ }^{2}$ Department of Molecular Biology \\ and Genetics, Johns Hopkins University School of Medicine, Baltimore, Maryland 21205 USA
}

\begin{abstract}
The gypsy element of Drosophila differs from most LTR retrotransposons in containing a third open reading frame that resembles retroviral env genes. The protein encoded by ORF3 is glycosylated and processed, like all retroviral envelope proteins. The protein is expressed at high levels in fly strains in which gypsy elements are active. In these strains the protein is found primarily in viral particles. When larvae of fly strains in which gypsy is normally inactive are exposed to sucrose gradient fractions containing these particles, a high level of gypsy insertion activity is observed in their progeny. Thus, gypsy has the expected properties of an insect retrovirus.
\end{abstract}

[Key Words: Drosophila; mutagenesis; transposable element; insect retrovirus]

Received May 6, 1994; revised version accepted July 11, 1994.

The gypsy element of Drosophila melanogaster has been classified traditionally as a long terminal repeat (LTR) retrotransposon; however, it is one of a small group of LTR retrotransposons from insects that are unusual in that they contain three open reading frames (ORFs). In these retroelements, the first two ORFs correspond to retroviral gag and pol, whereas ORF3 is of unknown function but corresponds in size and genomic location to retroviral env (Fig. 1). All elements with three ORFs described so far are from insects, either Drosophila or the lepidopteran Trichoplusia ni. Recent results have shown that in two elements encoding an ORF3, gypsy and tom, a subgenomic mRNA similar in structure to retroviral env mRNAs can be found (Pélisson et al. 1994; Tanda et al. 1994). In the case of gypsy, this transcript is observed only in certain strains in which gypsy transpositional activity is high (Pélisson et al. 1994). The primary sequences of the encoded ORF3 proteins of these elements are quite variable and show no obvious similarity to retroviral Env proteins. However, retroviral Env proteins are themselves very variable in primary sequence. Like retroviral Env proteins, the proteins encoded by "retrotransposon" ORF3s contain a putative transmembrane domain near their carboxyl terminus, multiple putative $\mathrm{N}$-glycosylation sites, and putative protease cleavage sites (resembling the cleavage sites in a variety of retroviral Env proteins) at conserved positions (Fig. 1). These features of gypsy and the other ORF3-containing insect retrotransposons have prompted the suggestion that these elements may represent endogenous insect retro-

${ }^{3}$ Corresponding authors. viruses (Boeke 1988; Boeke and Corces 1989; Coffin 1993).

To address the question of whether gypsy represents a virus or a transposon more directly, we have turned to the use of Drosophila strains that show genetic instabilities associated with high-frequency insertion by gypsy elements. These strains are characterized by a large number of full-length gypsy elements in the euchromatin, appearance of gypsy insertion mutations at high frequency, and the presence of both large amounts of gypsy full-length RNA and spliced ORF3 mRNA (Pélisson et al. 1994; N. Prud'homme, M. Gans, M. Masson, C. Terzian, and A. Bucheton, in prep.).

Mobilization of gypsy can be detected by a sensitive assay using the female-sterile mutation $o v o^{D 1}$. This dominant mutation has no effect on males but prevents development of the female germ line. gypsy insertion into the ovo ${ }^{D 1}$ allele results in its conversion into a recessive ovo allele (Mével-Ninio et al. 1989). Thus, heterozygous $\mathrm{ovo}^{D 1} /$ + females are sterile, whereas females in which gypsy insertions into $O{ }^{D} O^{D 1}$ occurred during germ-line development are able to produce progeny. When $o v o^{D 1}$ males are crossed to females of gypsy-active backgrounds, a high frequency of $O{ }^{D} O^{D 1}$ reversion is observed; many of these reversion events are caused by gypsy or copia insertion (Mével-Ninio et al. 1989). No such reversion is observed when $\mathrm{ovo}^{D 1}$ males are crossed to females of the SS line, in which gypsy is inactive (Kim et al. 1994). The characteristic of high-frequency gypsy transposition is conferred by the flamenco gene on the $\mathrm{X}$ chromosome; females of the $y \mathrm{v} f \mathrm{mal}$ flam strain must be homozygous for the $\mathrm{X}$ chromosome for high-fre- 


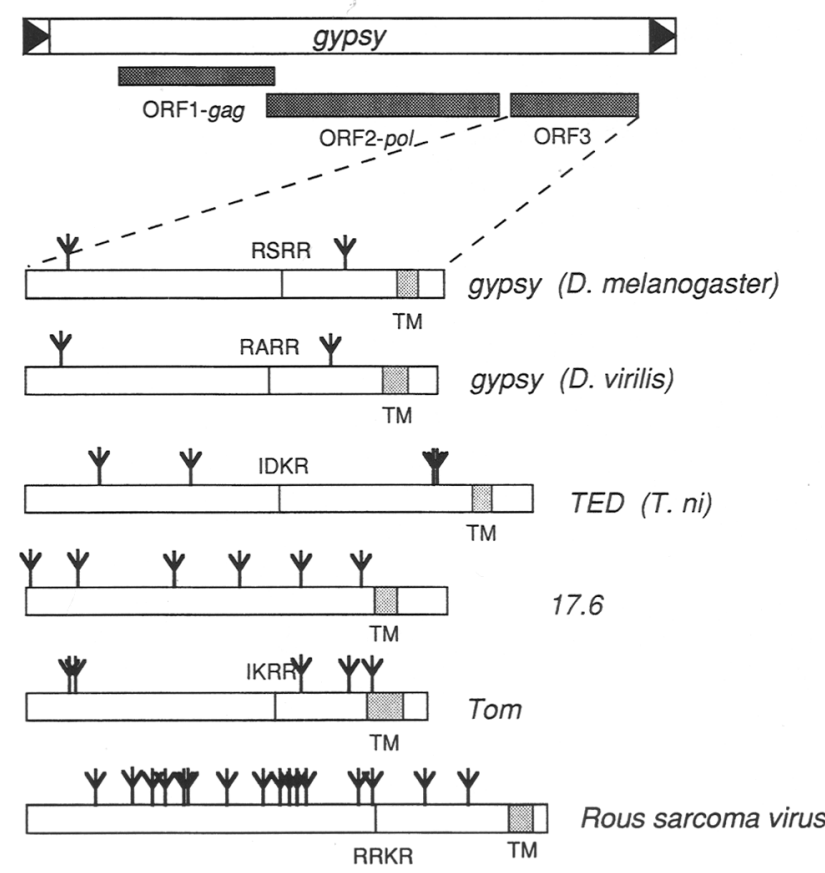

Figure 1. ORF3 of certain insect retroelements encodes a protein resembling retroviral env. Overall structure of gypsy DNA (Marlor et al. 1986) is indicated at top. ORF3s have been described from a handful of insect LTR retroelements; the conserved aspects of the structures of their predicted proteins are indicated to scale in the lower panel. (Forks) Putative N-linked glycosylation sites [only those amino-terminal to the proposed transmembrane (TM) domains are indicated]; (stippled boxes) TMs; (vertical lines with tetrapeptide motifs) putative dibasic cleavage sites. All elements are from $D$. melanogaster except as indicated. Note that all features are well-conserved between the $D$. melanogaster and $D$. virilis gypsy elements, despite their $20 \%$ amino acid sequence divergence /Mizrokhi and Mazo 1990). TM domains were predicted by Kyte-Doolittle hydropathy plots using DNA Strider 1.2 (Marck 1988).

quency gypsy insertion to occur in their progeny $(\mathrm{N}$. Prud'homme, M. Gans, M. Masson, C. Terzian, and A. Bucheton, in prep.). Thus, there is a maternal effect of the flam gene that determines gypsy mobilization. This suggests that a critical flam-controlled step must occur in the ovaries of the mother to determine whether gypsy insertion will occur in the subsequent generation. ORF3 protein is expressed in the ovarian follicle cells of these strains (Pélisson et al. 1994), suggesting that virus assembly might be occurring in this tissue. Preliminary support for the idea of an infectious gypsy virus came from the studies of Kim et al. (1994), who have shown that microinjection of crude egg plasm from active strains into inactive strain embryos (or feeding of pupal extracts to larvae) results in detection of subsequent gypsy insertions in the progeny of the recipients using the $O V O^{D 1}$ reversion assay. Because these experiments made use of extremely crude preparations, we have examined whether an infectious particle with the characteristics of a retrovirus is present in the ovaries of flam females and might be responsible for the subsequent gypsy insertions. We find expression of gypsy ORF3 protein products in the ovaries of these flies and show that these proteins have Env-like characteristics. Furthermore, we provide direct evidence for infectious gypsy virus particles in these tissues.

\section{Results}

Env-like proteins encoded by gypsy ORF3 are expressed in ovaries of flam females

gypsy encodes a subgenomic mRNA for ORF3 of $2.2 \mathrm{~kb}$; the sequence of this mRNA predicts a protein of $54 \mathrm{kD}$ (Pélisson et al. 1994). The ORF3 protein contains a putative signal peptidase cleavage site as well as a dibasic cleavage site resembling those in retroviral Env protein precursors. Cleavage at these sites would result in a surface protein of $32 \mathrm{kD}$ and a trans-membrane protein of 20 $\mathrm{kD}$ (Fig. 1); these values do not take into account unpredictable variations that may result from glycosylation. To investigate the nature of gypsy ORF3 proteins, monoclonal antibodies were raised against a trpE-ORF3 fusion protein (see Materials and methods). Two monoclonal antibodies (mAb), 7B3 and 8E7, were isolated, which reacted specifically with the ORF3 portion of the fusion protein. These antibodies were used to probe immunoblots of SDS-polyacrylamide gels on which various ovary extracts or in vitro translation products were separated. Both antibodies react specifically with the ORF3 portion of fusion proteins (Materials and methods), as well as an in vitro translation product expressed from a T7-ORF3 expression construct (Fig. 2C). The in vitrotranslated protein migrates with an apparent molecular mass of $60 \mathrm{kD}$.

Using either antibody, ORF3-specific protein bands of 66 and $54 \mathrm{kD}$ are observed in the $y \mathrm{v} f \mathrm{mal}$ flam (referred to from this point on simply as flam) ovary extracts (Fig. 2A). In addition, antibody $7 \mathrm{~B} 3$ reacts with a protein of 28 $\mathrm{kD}$. These protein bands are absent in Ore-R and flam/ + heterozygotes and, thus, represent native gypsy ORF3 proteins. The presence of multiple ORF3-specific species suggests that post-translational modifications and proteolytic cleavages may have occurred.

gypsy insertion activity, as measured by the $o v O^{D 1}$ reversion assay, is known to be influenced by the age at which the females are mated to the ovo ${ }^{D 1}$ males (Pélisson et al. 1994; N. Prud'homme, M. Gans, M. Masson, C. Terzian, and A. Bucheton, in prep.). The expression of ORF3 protein peaks at the same age (i.e., in 1- to 3-dayold females) as does gypsy activity in the $O V O^{D 1}$ reversion assay, and is absent in strains heterozygous for the flam $\mathrm{X}$ chromosome (Fig. 2B). Thus, the pattern of expression of ORF3 mRNA and protein parallels that of gypsy insertion activity.

If ORF3 encodes an envelope protein, it is expected to be a glycoprotein, as is the case for retroviral Env proteins (see Fig. 1). This hypothesis was tested by immunoblotting of ovary extracts with and without treatment with endoglycosidase $F$ (EndoF) and comparison to in 


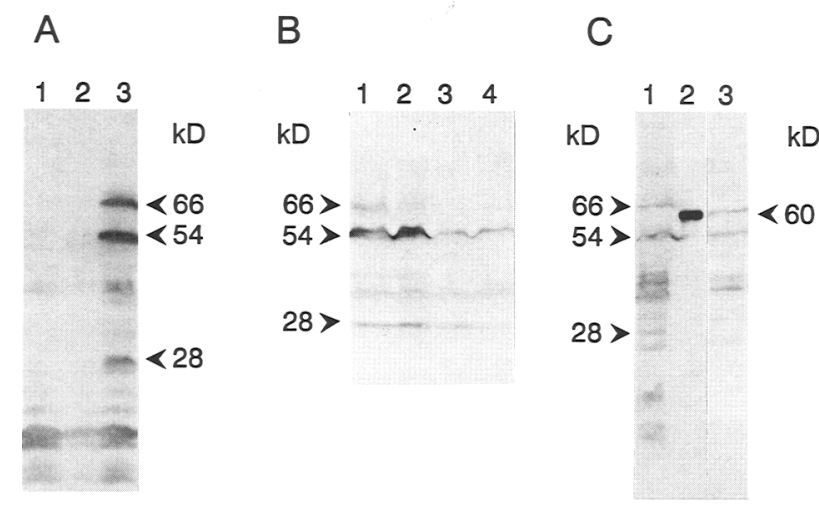

Figure 2. ORF3 glycoprotein is expressed and processed in flam strains. Ovary extracts were run on PAGE and immunoblotted with antibody 7B3. flam-Specific bands are indicated with an arrowhead. (A) Specific expression of ORF3 in flam strains. Approximately $70 \mu \mathrm{g}$ of protein was run per lane. (Lane 1) Ore-R $\left(\right.$ flam $\left.^{+}\right)$; (lane 2) flam/ + heterozygote; (lane 3) flam homozygote; $12 \%$ PAGE. $(B)$ Time course of ORF3 protein expression. Ovaries were extracted from flies of various ages: (Lane 1) 2-3 days; (lane 2) 4-5 days; (lane 3) 6-7 days; (lane 4) $8-9$ days; $15 \%$ PAGE. (C) ORF3 protein is glycosylated. Ovary extracts were run without pretreatment (lane 1) or after EndoF treatment (lane 3); also included in lane 2 is in vitro-translated ORF3 protein; $12 \%$ PAGE. vitro-synthesized ORF3 protein. As can be seen from Figure $2 \mathrm{C}$, EndoF treatment reduces the apparent molecular mass of the $66-\mathrm{kD}$ species such that it comigrates with ORF3 protein translated in vitro.

\section{ORF3 proteins are associated with virus-like particles}

Extracts of 3- to 5-day-old flam and control Oregon R (Ore-R) $\left(\right.$ flam $\left.^{+}\right)$females were prepared and subjected to sucrose density gradient analysis. Figure 3 shows the result of reverse transcriptase (RT) assays using poly(A)oligo(dT) primer template and immunoblotting analyses done on the gradient fractions. In both strains three peaks of RT activity were observed, but the second peak is larger in the flam extract. gypsy-specific ORF3 proteins were observed primarily in the flam gradient where they were readily detected with both mAbs in the second peak, in which the proteins were abundant. A small amount of protein cross-reacting with ORF3 antibodies was seen in the first peak of both strains.

Peak 2 fractions from both the flam and Ore- $R$ gradients were concentrated and examined by immunoelectron microscopy using mAbs 7B3 and 8E7 and colloidal gold-labeled goat anti-mouse IgG. Virus-like particles of irregular shape and $\sim 100 \mathrm{~nm}$ in diameter were observed

Figure 3. Sucrose density gradient analysis of gypsy particles. RT profiles from two independent viral particle preparation experiments (gradient experiments 2 and 1 , respectively/ are presented $(A, B)$. (O) flam; ( $\square)$ Ore-R. The input extracts contained equal amounts of protein. The indicated fractions of gradient 2 were immunoblotted with the $7 \mathrm{~B} 3$ antibody $(C, D)$; similar results were obtained with the 8E7 antibody (not shown). Lanes $A$ and $B$ in these panels contain ovary extract from flam flies and in vitro-translated ORF3 protein, respectively. Samples $A$ and $B$ were frozen and thawed once between the time gels $C$ and $D$ were run; this may account for the larger amount of apparent degradation products in lane $A$ of

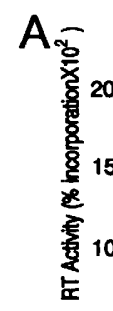

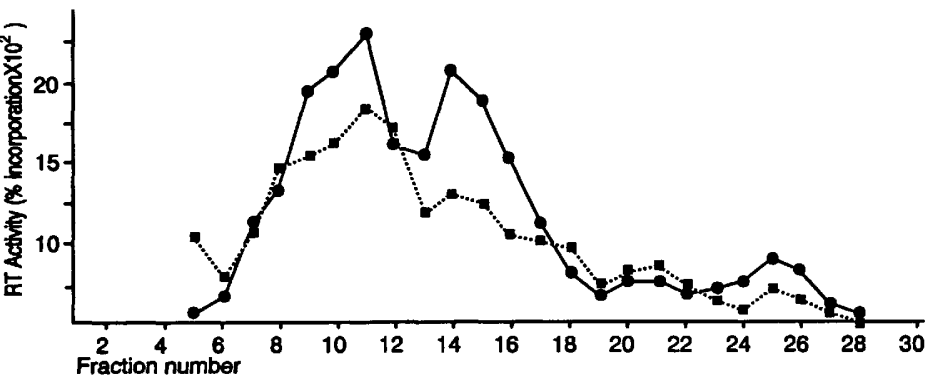
panel $D$.
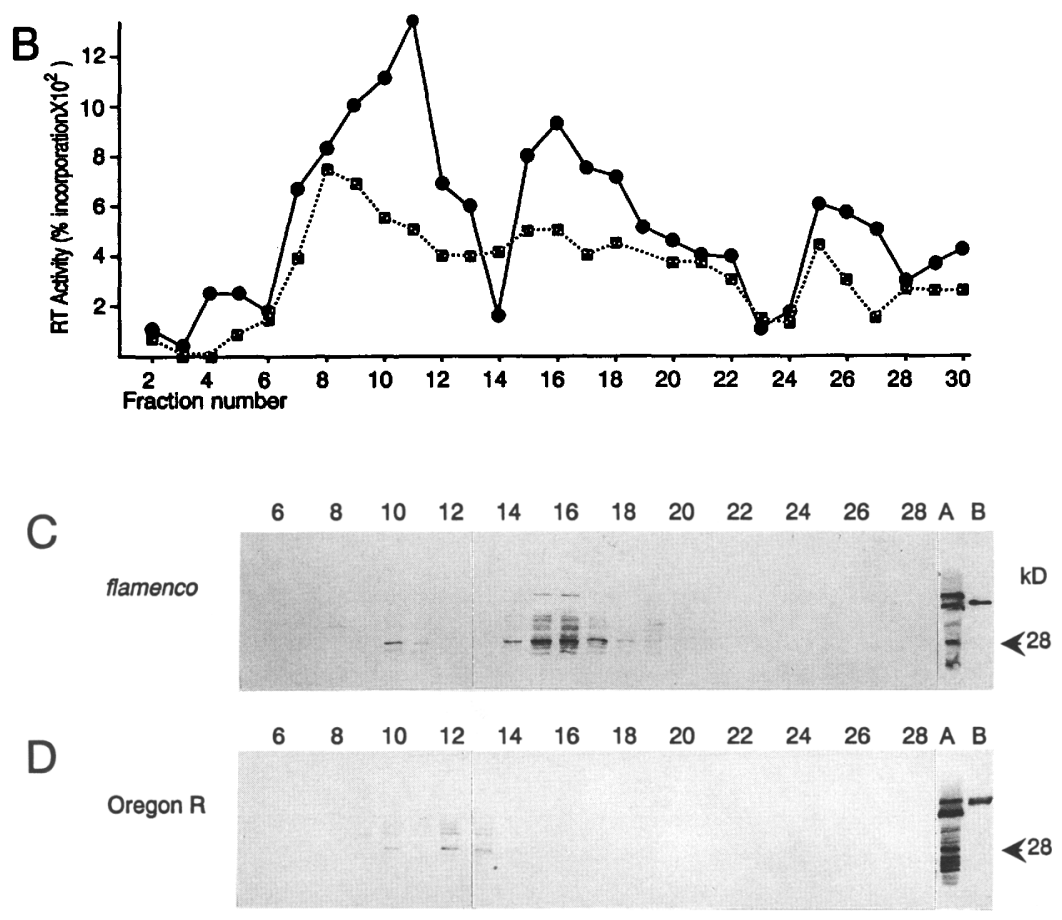
and decorated by the gold particles; no such particles were observed in the control fractions (Fig. 4). There are also clusters of gold particles associated with what appear to be small fragments of membrane in the flam gradient fractions only. These may represent envelope proteins sloughed off of gypsy particles.

\section{gypsy-specific endogenous $R T$ products}

Endogenous RT reactions, in which only triphosphates (one of which was radioactive) but no primers or templates are supplied, were carried out with material from the three peaks. The products of these reactions were then deproteinized and used as hybridization probes against DNA blots containing Drosophila gypsy, copia, 412, and 17.6 element DNAs (Fig. 5). All three peaks contained some products that hybridized to gypsy. The material from the second peak hybridized only to gypsy, whereas the material from peaks 1 and 3 hybridized to copia, 412, and 17.6 (not shown). We conclude that peak 2 contains particles containing both gypsy RNA and RT, and relatively little other retroelement particles. Peak 1 may represent soluble material or partially disrupted particles with little specificity, and peak 3 (which is the position at which nonenveloped and, hence, much denser yeast Tyl particles band on this type of gradient) probably contains a variety of nonenveloped particles.

\section{Exposure of larvae of gypsy-inactive strains to particulate fractions results in $\mathrm{ovo}^{\mathrm{D} 1}$ reversion}

An experiment was designed to detect infectious gypsy viruses in the gradient fractions containing ORF3 pro- tein. This experiment takes advantage of the sensitivity of $o v O^{D 1}$ to insertion by gypsy. These experiments made use of the SS strain, which although it is a flam strain, does not support high-level gypsy mobility because it lacks active gypsy sequences. We attempted to compensate for the latter defect by introducing gypsy virus particles by feeding. The SS strain was raised in the presence of material derived from the second peak throughout the larval period of development; $25 \mu \mathrm{l}$ of a concentrated peak gradient fraction was mixed gently into the food every 2 days. Although this is sometimes referred to as a "feeding" experiment, we note that these larvae were also exposed to the gradient material externally. Females emerging from these vials were crossed to $O{ }^{D} O^{D 1}$ males. Approximately 1000 individual female progeny from this cross were crossed to Ore- $\mathrm{R}$ males and monitored for fertility. Approximately $1.5 \%$ of these females were fertile, indicating reversion of $o v O^{D 1}$, whereas no such revertants were observed in unfed control flies or flies fed the Ore- $\mathrm{R}$ gradient fraction (Table 1). These results are highly significant statistically (fed vs. unfed, $P=0.0001$; flam vs. Ore-R, $P=0.091$ ).

\section{Certain ovo $^{\mathrm{D} 1}$ reversions are caused by gypsy insertion}

The $O V O^{D 1}$ revertants and their progeny were analyzed by a PCR method as well as by in situ hybridization with gypsy and copia probes. Sixteen revertants were obtained in total from the feeding experiment; 14 of these gave rise to multiple progeny and could be used to establish new lines (Table 2). For PCR analysis, DNA was prepared from $\sim 30 \mathrm{~F}_{2}$ progeny from each line to be tested and amplification was carried out with oligonucleotide prim-
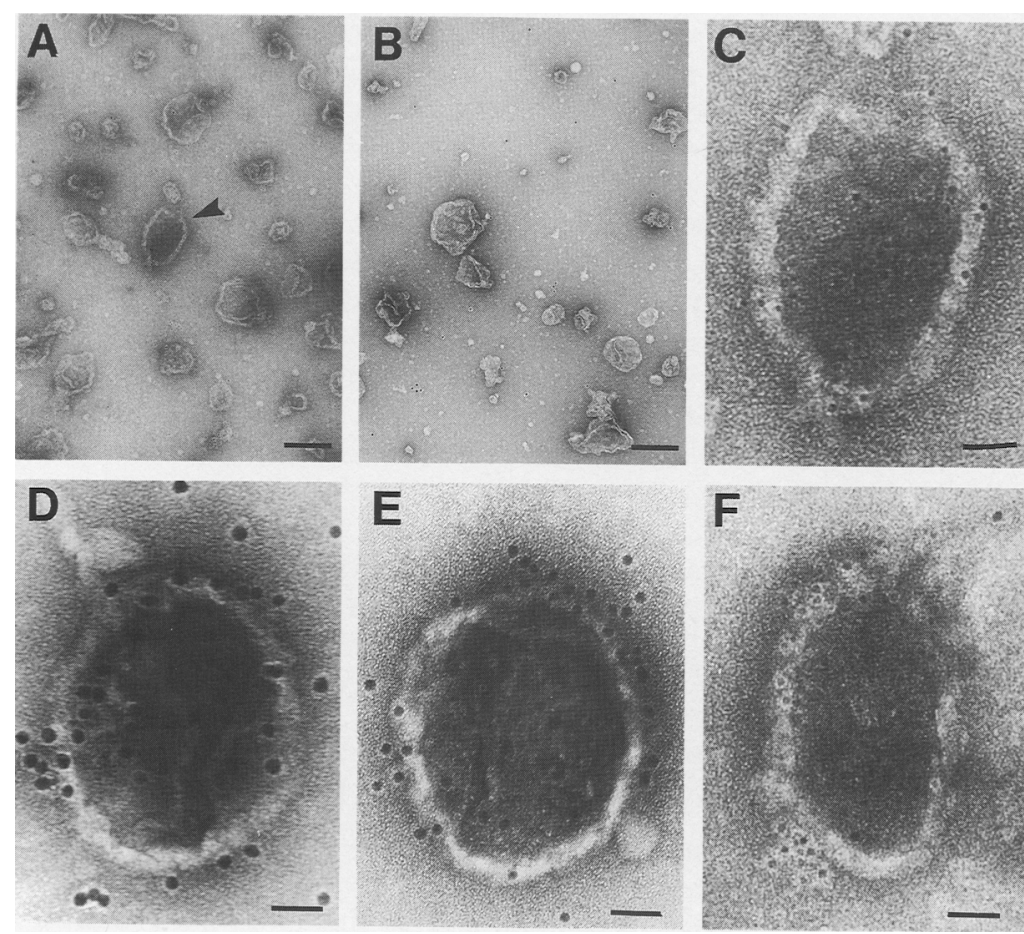

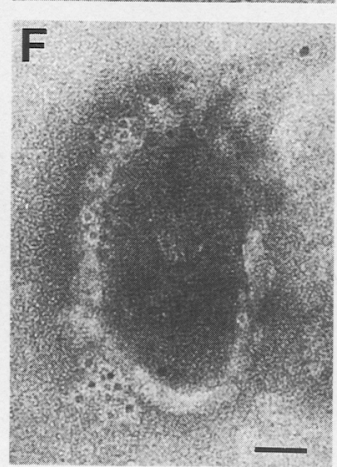

Figure 4. Immunoelectron microscopy. Fractions 14-19, concentrated as described from gradient experiment 1 , were examined by negative staining and immunoelectron microscopy. $(A, C-$ $F)$ the flam gradient; $(B)$ the Ore-R gradient. $A, B$, $C$, and $F$ were stained with 5 -nm gold particles; $D$ and $E$ were stained with 10 -nm gold particles. Bars, $100 \mathrm{~nm}(A, B) ; 20 \mathrm{~nm}(C-F)$. 
Figure 5. gypsy-specific RT products. $(A)$ Plasmids containing the indicated Drosophila retrotransposons were cleaved with different restriction enzymes and the fragments were separated electrophoretically. The DNA was then blotted to nitrocellulose. $(B)$ The product of an endogenous reaction using material from fractions $15-17$ of the flam gradient 1 were separated from unincorported nucleotides by Sephadex G50 chromatography and used as a hybridization probe.
A

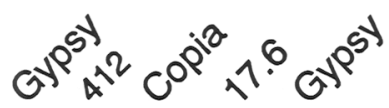

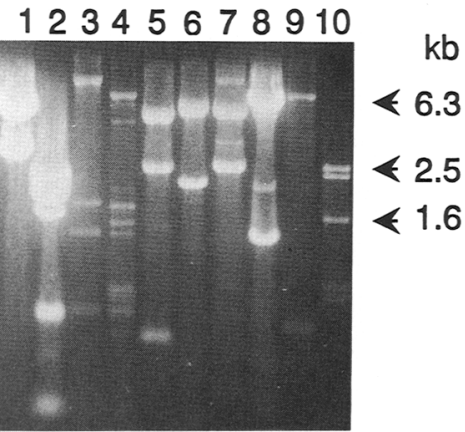

B

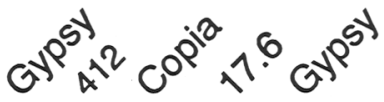

12345678910

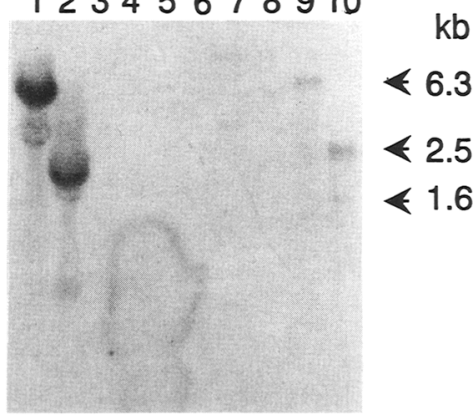

ers derived from the ovo locus or the gypsy terminus (Fig. 6). As expected, all samples gave rise to a wild-type ovo band, indicating at least one unrearranged ovo locus. Four of the revertants gave rise to PCR products whose size was consistent with that of previously isolated gypsy insertions in ovo (Mével-Ninio et al. 1989). Three of these PCR products, as well as the wild-type ovo PCR product, were sequenced and were shown to represent gypsy insertions into ovo (Fig. 6). All three sequenced insertions were different, and none of these insertion sites were exact matches to the previously proposed gypsy target site consensus sequence; instead, they conformed to the more general consensus sequence YRYRYR [(Y) pyrimidine; (R) purine].

The remaining revertants were analyzed by in situ hybridization with gypsy and copia probes. Three additional lines were shown to contain gypsy insertions in $4 \mathrm{E}$, the cytological location of ovo. The remaining seven lines all showed hybridization of the copia probe to $4 \mathrm{E}$ (Fig. 7). Insertion of copia into ovo is not completely unexpected because it was observed in a previous study in which the $y \mathrm{v} f$ mal flam strain was crossed to ovo ${ }^{D 1}$ (Mével-Ninio et al. 1989). Thus, all 14 lines tested contained an insertion of either a gypsy or a copia element at the ovo locus, at least at the resolution of in situ hybridization. In addition to the gypsy elements inserted at $4 \mathrm{E}$, additional sites of new gypsy insertion were detected in many of the revertant lines.

Table 1. Feeding of particulate fractions results in ovo $^{\mathrm{D} 1}$ reversion

\begin{tabular}{lcccc}
\hline & $\begin{array}{l}F_{0} \\
\text { females } \\
\text { studied }\end{array}$ & $\begin{array}{l}\text { Total } \\
F_{1} \\
\text { females } \\
\text { tested }\end{array}$ & $\begin{array}{l}\text { Fertile } \\
F_{1} \\
\text { females }\end{array}$ & $\begin{array}{l}\text { Reversion } \\
\text { frequency } \\
(\%)^{\mathbf{b}}\end{array}$ \\
\hline flam fraction & 31 & 1048 & 16 & $\begin{array}{c}1.53 \\
\text { Ore-R fraction }\end{array}$ \\
Control unfed & 33 & 451 & 0 & $<0.2$ \\
\hline
\end{tabular}

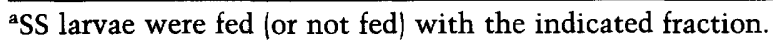
${ }^{b}$ The literature value for reversion of $o v 0^{D 1}$ is $0.01 \%$ (MévelNinio et al. 1989).

\section{Unusual properties of ovo $^{\mathrm{Dl}}$ revertant progeny}

The $\mathrm{F}_{2}$ progeny of $o v O^{D 1}$ revertants show a number of unusual properties (Table 2). The phenotype of the $\mathrm{F}_{2}$ males is expected to be $50 \%$ white-eyed and $50 \%$ redeyed because of the heterozygous white $(w)$ mutation expected to be present in the SS mother. However, the observed result was that within any one line, males were either all white eyed (6 lines; Table 2 ) or all red eyed ( 8 lines). This behavior differs from that of crosses in which gypsy was introduced directly by crossing flam females $\times \mathrm{ovo}^{D 1}$ males. In this case, individual revertant lines gave rise to a mixture of yellow ${ }^{+}$and yellow male progeny.

The unusual segregation of the $w$ marker in the male progeny of these crosses is difficult to explain. There are two classes of such lines: those that give only white-eyed male progeny and those that give rise to only red-eyed male progeny. In principle, the former class could be explained by a mitotic recombination event that resulted in homozygosis of the $\mathrm{X}$ chromosome, resulting in homozygosity for $\mathrm{OVO}^{+}$and $w$. However, this cannot explain our results because some of these lines show evidence of gypsy or copia insertion at 4E, which would not have been selected for were the ovo reversion already accounted for by homozygosis. Sex ratios of the progeny were not unusual in any of these lines; however, recessive lethality was associated with three of the $\mathrm{X}$ chromosomes that we studied (data not shown).

Several of the lines derived by feeding of particles showed both somatic and germ-line instabilities in the $\mathrm{F}_{2}$ generation and beyond. Apparent somatic mutations with phenotypes corresponding to $w$ and Lobe were observed. Also, new mutations were observed in the subsequent generations with a variety of mutant phenotypes (Table 2).

\section{gypsy insertions in SS strain after exposure of larvae to particulate fractions}

In a second feeding experiment, SS larvae that were fed particulate fractions were simply mated to unexposed SS flies. The progeny larvae from this cross were examined 
Table 2. Characteristics of fertile derivatives of fed larvae

\begin{tabular}{|c|c|c|c|c|c|c|c|c|c|c|c|c|c|c|c|c|}
\hline Revertant & 1 & 2 & 3 & 4 & $5^{a}$ & 6 & 7 & 8 & 9 & 10 & 11 & 12 & 13 & 14 & 15 & $16^{a}$ \\
\hline $\mathrm{PCR}^{\mathrm{b}}$ & - & - & - & - & N.D. & - & - & + & + & - & + & - & - & - & + & N.D. \\
\hline $\begin{array}{l}\text { In situ } \\
\text { Germ-line } \\
\text { mutations }^{c}\end{array}$ & $\begin{array}{l}\text { copia } \\
\text { held-up } \\
\text { bristle }\end{array}$ & copia & copia & $\begin{array}{l}\text { gypsy } \\
y \\
\text { bristle }\end{array}$ & N.D. & $\begin{array}{l}\text { copia } \\
\text { wing }\end{array}$ & $\begin{array}{l}\text { gypsy } \\
y\end{array}$ & $\begin{array}{l}\text { N.D. } \\
\text { bristle }\end{array}$ & $\begin{array}{l}\text { gypsy } \\
\text { wings } \\
\text { apart }\end{array}$ & copia & $\begin{array}{l}\text { N.D. } \\
\text { singed }\end{array}$ & copia & copia & $\begin{array}{l}\text { gypsy } \\
\text { small } \\
\text { wings }\end{array}$ & N.D. & N.D. \\
\hline $\begin{array}{l}\text { Somatic } \\
\text { mutations }\end{array}$ & white & & $\begin{array}{l}\text { white } \\
\text { loz }\end{array}$ & & & & & $\mathrm{loz}$ & $\operatorname{loz}$ & & $\begin{array}{l}\text { lobed } \\
\text { eye }\end{array}$ & & & loz & & \\
\hline
\end{tabular}

${ }^{a}$ Lines 5 and 16 had only one or two progeny and were not studied further.

bPresence (+) of band with PCR with either primer pairs P1 and P2 or P3 and P2 (see Fig. 6) or absence (-) of either band. (N.D.) Not determined. 'Heritable mutant phenotypes resembling known mutations are indicated. (bristle) Thin (or thick) and short bristles; (wing) crumpled wings; (loz) lozenge-like; (held-up) held-up wings.

${ }^{\mathrm{d}}$ Individual somatic mutations affecting eye color (white) or structure (lobed), identified phenotypically.

directly by in situ hybridization with a gypsy probe. Because the SS strain contains only two gypsy elements in its euchromatin, and these together with the few elements in the heterochromatin are inactive (Kim et al. 1994), new gypsy copies present in these progeny must have derived from the donor (flam) strain. More than half of the larvae examined had new euchromatic gypsy insertions, demonstrating that a high frequency of gypsy insertion is observed even in the absence of any selection for special mutations such as reversion of ovO $^{D 1}$ (Fig. 7; Table 3). In contrast, no new insertions were seen when 14 unfed SS larvae were examined (fed vs. unfed, $P=0.001)$. The new insertions were observed both when fed females were crossed to unfed males and vice versa, suggesting that both male and female germ lines can be infected. Among the new gypsy insertions observed were two to five insertions into the $4 \mathrm{E}$ region of the $\mathrm{X}$ chromosome, providing strong evidence that this region of the X chromosome represents an especially hot spot for gypsy insertion. No new copia insertions were observed in this experiment, suggesting that simple feeding of particulate fractions is not sufficient to effect the activation of copia transposition.

\section{Antibody inhibits gypsy activity}

In a separate feeding experiment, we fed particulate fractions that had been preincubated with purified mAbs: either the gypsy ORF3-specific antibodies or a control antibody raised against Tyl integrase protein. The assay described above was used to monitor gypsy insertion activity in the SS strain. The number of new insertions was reduced about fourfold in the flies that were fed with particles preincubated with anti-ORF3 relative to the flies fed particles preincubated with anti-Tyl integrase (Table 4; anti-ORF3 vs. Tyl, $P=0.019$ ). In addition, by
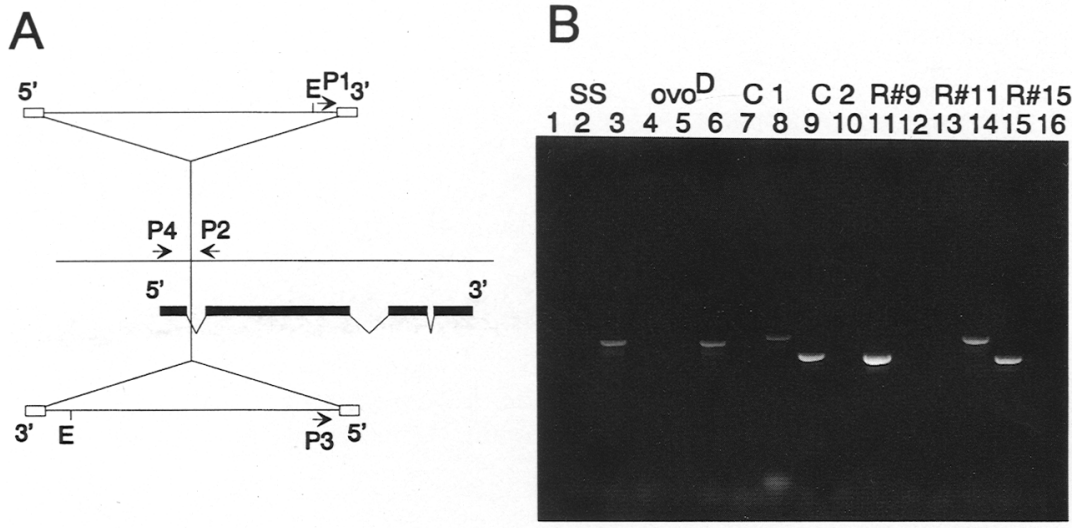

C

R\#15 TTGGAACTTATATAATT tatacatatgattaattcgtattlaaagta

$$
\text { gypsy } 998 \quad \text { ovo }
$$

R\#9 TTGGAACTTATATAATTtacatatgattaattcgtatttaaagtaac

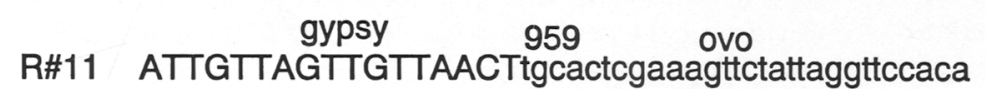

Figure 6. PCR and sequence analysis. $(A)$ The structure of the ovo locus (Mével-Ninio et al. 1991) is presented, indicating the position of some of the gypsy insertions analyzed in this study. (Solid bars) Putative exons; (V shapes) introns; (open bars) LTRs; (arrows) PCR primers used. $(B)$ PCR products. DNA from the indicated strains was used as a template for PCR using the following primer pairs: $(\mathrm{P})$ (Lanes $1,4,7,9,11,13,15) \mathrm{P} 1$ and $\mathrm{P} 2$; (lanes 2,5,8,10, 12,14,16) P3 and P2; (lanes 3,6) P4 and P2. Revertant strains $\mathrm{C} 1$ and $\mathrm{C} 2$ were obtained by crossing the flam strain directly to the $o v O^{D 1}$ strain; revertants $\mathrm{R} 9, \mathrm{R} 11$, and $\mathrm{R} 15$ were obtained by feeding virus particles. $(C)$ Junction sequences determined. The gypsy terminal sequences are indicated in upper case and the flanking ovo sequences in lower case. 
Figure 7. In situ hybridization. $(A)$ copia in situ hybridization on $o v o^{D 1}$ revertant 2; (B) gypsy in situ hybridization on SS feedant $5-7 ;(C)$ copia in situ hybridization on the SS strain; $(D)$ gypsy in situ hybridization on SS. See Table 3 for additional data on SS feedants.
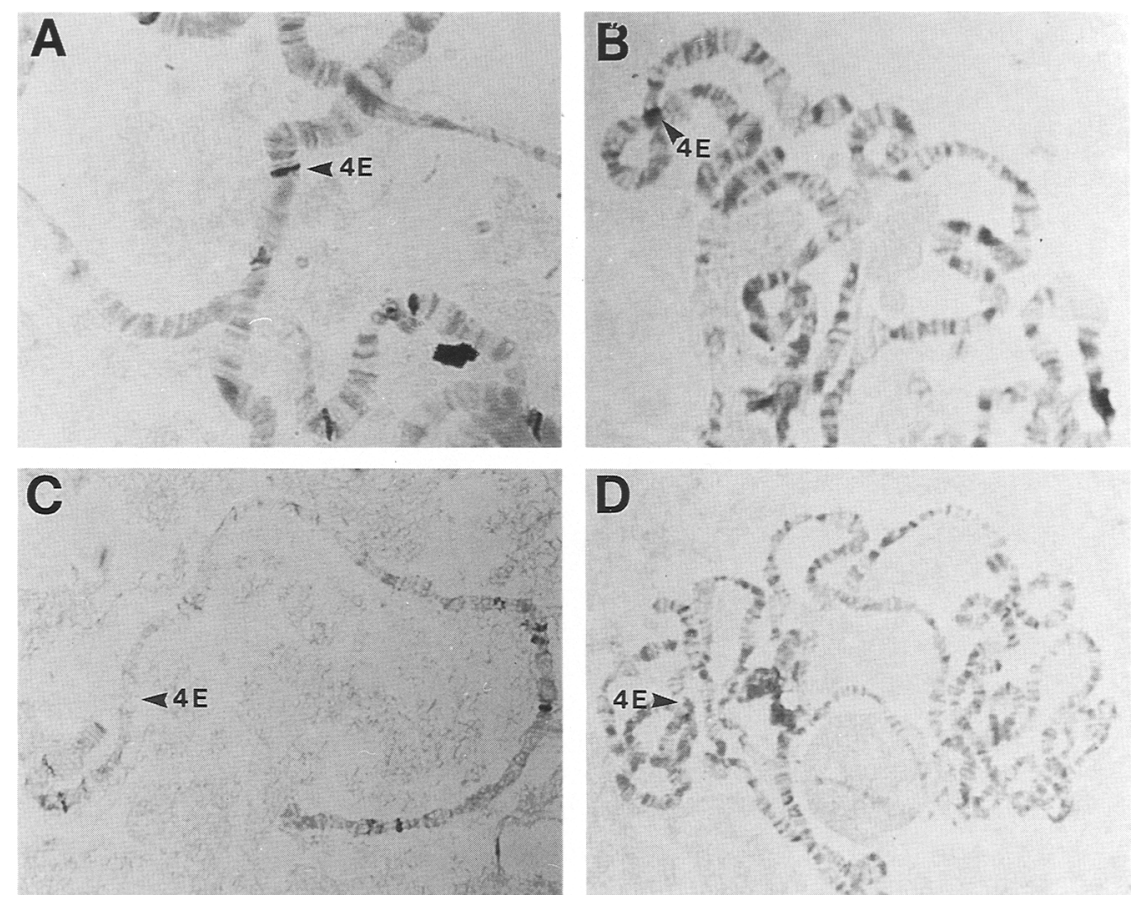

the $o v O^{D 1}$ reversion assay, there was also a fourfold inhibition of $O V O^{D 1}$ reversion conferred by pretreatment with anti-ORF3 antibody (Table 4; anti-ORF3 vs. Ty1, $P=0.045$ ). Thus, the anti-ORF3 antibodies appear to exert a partially protective effect against the gypsy virus particles.

\section{Discussion}

\section{Evidence that ORF3 is env-like}

Our experiments show that ORF3-containing fractions also contain a gypsy-specific RT activity, which is capable of producing gypsy-specific cDNA species. These results suggest that gypsy RNA and gypsy primer tRNA for partially synthesized gypsy cDNAs) cosediment with RT in the sucrose gradient. Furthermore, we observe viruslike particles by immunoelectron microscopy of the same fractions using an anti-ORF3 antibody. Neither the activity nor the virus-like particles (VLPs) are observed in a control gradient prepared from a flam ${ }^{+}$strain. These observations provide strong evidence for a mature gypsy virus particle that contains ORF3 protein. The peak position of these gypsy particles in the sucrose gradients (fraction 16) is very different from that of control Tyl particles from yeast, which peak at fraction 25 under these conditions. This may be because the gypsy particles contain a membranous envelope that would greatly reduce their density relative to Tyl particles, which lack an envelope. In support of this notion, a second peak of gypsy-specific RT activity is found at fractions 25-28; these fractions lack ORF3 protein completely. copia and 412 RTs are also found in these fractions; neither copia nor 412 have an ORF3 and, thus, are more like yeast Tyl.
We suspect that this peak of gypsy activity represents either partially assembled gypsy particles or partially degraded particles that lack an envelope. A previous study

Table 3. New gypsy and copia copies in derivatives of SS strain that were fed gradient fractions

\begin{tabular}{rlc}
\hline Line & $\begin{array}{l}\text { New gypsy } \\
\text { copies (no.) }\end{array}$ & $\begin{array}{c}\text { New copia } \\
\text { copies (no.) }\end{array}$ \\
\hline $1-2$ & 0 & 0 \\
$2-1$ & 1 & 0 \\
$2-2$ & 0 & \\
$3-1$ & 0 & \\
$4-1$ & 1 & 0 \\
$5-1$ & 2 & \\
$5-2$ & 1 & \\
$5-3$ & 3 (including 4E insertion) & 0 \\
$5-6$ & 0 & 0 \\
$5-7$ & 2 (including 4E insertion) & \\
$8-1$ & 0 & 0 \\
$8-2$ & 0 & \\
$8-3$ & 2 (including 4E insertion) & 0 \\
$8-4$ & 2 (including 4E insertion) & 0 \\
$8-5$ & 4 & 0 \\
$8-6$ & 0 & \\
$8-7$ & 3 (including 4E insertion) & \\
$8-8$ & 0 & (including 4E insertion) \\
$10-1$ & 2 & \\
\hline
\end{tabular}

New gypsy and copia copies were detected by in situ hybridization. Progeny, e.g., $2-1$ and 2-2, are siblings. For lines $1-2$ and $10-1$, a fed male was crossed to an unfed female. For all other lines, a fed female was crossed to an unfed male. The $4 \mathrm{E}$ insertions in 8-3, 8-4, and 8-7 may not be independent. In a control experiment, 14 unfed SS larvae were examined and 0/14 had new copies of gypsy. 
Table 4. Antibody inhibition

\begin{tabular}{lcc}
\hline & \multicolumn{2}{c}{ Antibody } \\
\cline { 2 - 3 } & anti-ORF3 $^{\mathrm{a}}$ & $\begin{array}{c}\text { anti-Tyl } \\
\text { integrase }^{\mathrm{b}}\end{array}$ \\
\hline $\begin{array}{l}\text { Feeding of SS strains, assay by in situ hybridization } \\
\text { number of new gypsy copies observed/ }\end{array}$ & $6 / 33$ & $22 / 33$ \\
number of strains checked by in situ $(\%)$ & $(18)$ & $(67)$ \\
ovo $^{D 1}$ reversion assay & & \\
number of fertile $\mathrm{F}_{1}$ females/ & $2 / 1030$ & $9 / 930$ \\
$\mathrm{~F}_{1}$ females tested $(\%)$ & $(0.19)$ & $(0.97)$ \\
\hline
\end{tabular}

${ }^{a}$ Mixture of $45 \mu \mathrm{g}$ of $7 \mathrm{~B} 3$ and $45 \mu \mathrm{g}$ of $8 \mathrm{E} 7$.

b90 $\mu \mathrm{g}$ of $8 \mathrm{~B} 11$ (Eichinger and Boeke 1988).

cPerformed as described for Table 1 .

reported tentative evidence for gypsy virus (or virus-like) particle production in tissue culture cells. A variety of virion types were found in extracellular fluid and were associated with some gypsy RNA, but no evidence was presented to identify definitively the gypsy particles (Syomin et al. 1993). It would be interesting to test the supernatants of such tissue culture cell lines for gypsy insertion activity by the ovo ${ }^{D 1}$ reversion assay.

We have shown that ORF3 protein is N-glycosylated by treatment of protein extracts with EndoF and observed a shift in the electrophoretic mobility of the ORF3 protein to a mobility very similar to that of in vitro-translated ORF3 protein. Because retroviral Env proteins are also $\mathrm{N}$-glycosylated, this result provides further support for the conclusion that ORF3 has an envlike function. N-linked glycosylation signals are conserved in the ORF3s of gypsy (both $D$. melanogaster and D. virilis), 17.6, 297, tom, and TED. Furthermore, the TED retroelement ORF3 protein has also been shown to be glycosylated in insect cells (P. Friesen, pers. comm.). Thus $\mathrm{N}$-glycosylation is apparently a conserved feature of this class of retroelement ORF3 proteins. Furthermore, the ORF3 protein appears to be cleaved into at least two smaller products that may correspond to retroviral surface and transmembrane proteins.

\section{Infectivity}

Supporting evidence for a virus intermediate in the gypsy insertion process comes from experiments in which the fractions containing the virus particles were introduced into the SS strain, which lacks active gypsy copies. These particles were introduced into the flies by exposing larvae to the fractions. Whether the gypsy particles enter the larvae by ingestion, by adsorption to external larval surfaces, or by some other larval surface is not clear. However, such exposure resulted in a high frequency of gypsy insertion into the ovo ${ }^{D 1}$ locus, as monitored by the reversion assay. Similar results to these were obtained by Kim et al. (1994), who microinjected whole embryo extracts of flam strains into SS embryos and exposed SS larvae to whole pupal extracts of flam strains. In our experiments, additional copies of gypsy were observed to have been inserted in these $O{ }^{D} O^{D 1}$ revertant lines as well, suggesting high gypsy activity in the established lines, and their progeny showed evidence of both germ-line and somatic mutations at high frequencies. Kim et al. (1994) made no mention of either additional insertions or continuing genetic instability in their ovo ${ }^{D 1}$ revertant lines; therefore, it is possible that by using purified particle fractions, much higher levels of gypsy are introduced than when the virus is transmitted by a cross.

In subsequent experiments in which SS larvae were exposed to particles, no selection for $O \mathrm{VO}^{D 1}$ reversion was carried out, and the larvae exposed to particles were simply crossed to unexposed SS flies. The $F_{1}$ progeny of these flies also had a very high frequency of unselected gypsy insertions. The latter experiment is important because it shows that there is no need for special selections to observe high-frequency gypsy infection/insertion. Remarkably, a large fraction of these flies carried a gypsy insertion at 4E, the cytological location of ovo.

By preincubating the particles with anti-ORF3 antibodies before feeding, we observed a nearly fouffold reduction in the number of new insertion events resulting from feeding, consistent with ORF3 protein being required for infection and subsequent insertion of gypsy.

\section{A hybrid dysgenesis-like phenomenon}

The progeny of the $o v o^{D 1}$ revertants showed a number of unexpected and, in some cases, difficult-to-explain properties. Many of these properties are reminiscent of the behavior of the progeny of hybrid dysgenic crosses. The first is the appearance of visible mutants in subsequent generations, as if genetic instability mediated by these viruses or other entities in the fractions to which the flies were exposed can be maintained over several generations. This is somewhat surprising because both ${ }^{o v O^{D 1}}$ strain and Ore- $\mathrm{R}$ fail to give rise to $\mathrm{OVO}^{+}$revertants at high frequency (N. Prud'homme, M. Gans, M. Masson, C. Terzian, and A. Bucheton, in prep.). If a flam mutation is necessary for gypsy mobilization, it is not obvious why additional gypsy insertions are seen in subsequent generations. Either the requirement for flam 
phenotype can be overridden by the very high gypsy virus load obtained by these flies, or perhaps preformed gypsy viruses can be physically transmitted to subsequent generations. The latter could also explain, at least theoretically, the appearance of somatic mutation in the subsequent generations.

A number of the $O v O^{D 1}$ revertant lines showed evidence for copia insertions at band $4 \mathrm{E}$, the known cytogenetic location of ovo. None of the parental strains in this experiment (i.e., ovo ${ }^{D 1}$, Ore-R, SS, or flam) carries a copia insertion at this position. Although we have not proven that the copia insertions are directly responsible for this class of $o v o^{D 1}$ reversion event, it does seem likely that this is the case. There are numerous additional examples among those we have examined by in situ hybridization of copia inserted at positions not corresponding to those of any of the parental lines. This result suggests (but does not prove) that copia transposition is somehow elevated in these lines. There are many reports in the literature suggesting that hybrid dysgenic lines show mobility of elements other than the transposon responsible for the dysgenesis (e.g., in P-M dysgenic strains; Gerasimova et al. 1984a,b; Lewis and Brookfield 1987), but these conclusions remain controversial and do not appear to represent a completely general phenomenon (Woodruff et al. 1987; Eggleston et al. 1988; Engels 1989), and the mechanism of mobility in these cases (i.e., transposition or homology dependent) is certainly unproven. In the case of copia mobilization by injection of gypsy viruses, two possible mechanisms could be imagined: (1) copia retrotransposition could be mobilized in trans by gypsy elements, that is, trans-capsidation, or (2) high-frequency gypsy infection/integration causes a DNA damage response to which copia land perhaps other transposable elements) are responsive. The first hypothesis seems unlikely given that copia and gypsy are molecular archetypes of the two major subclasses of the LTR retrotransposons and, hence, are about as dissimilar in sequence and structure as two LTR retrotransposons can be. Furthermore, much experimentation has shown that molecular hybrids between even rather closely related LTR retrotransposons are inactive for transposition. There is evidence that LTR retrotransposons in a variety of host organisms respond to global cellular regulatory pathways, including DNA damage pathways (Strand and McDonald 1985; Rolfe et al. 1986; McEntee and Bradshaw 1988). Thus, the latter explanation seems more plausible.

A number of reports in the literature implicate highfrequency gypsy insertion as correlated with genetic instabilities reminiscent of hybrid dysgenesis. These include the strains $U c$ (unstable chromosome), tuh (tumorous head), flam (used in this study), and MS (mutator strain). The $U c$ strain is characterized by a high frequency of chromosome rearrangements, new gypsy-induced germ line and somatic insertions, and the gradual appearance of sterility (Lim 1980; Lim et al. 1983; B.H. Judd, pers. comm.). Another stock that gave rise to many gypsy-induced insertion mutations bears a tuh $h^{1,3}$ mutation; this stock is also unstable with regard to the high- frequency gypsy insertion phenotype (Kuhn 1970; D. Kuhn, pers. comm.). The y $\mathrm{f}$ mal flam strain is known to give a high rate of gypsy-induced ${ }{ }^{D} \mathrm{D}^{D 1}$ reversion, as well as giving a high frequency of cut mutations (MévelNinio et al. 1989). The MS strain is characterized by a high rate of gypsy- and hobo-induced mutations, especially cut and forked mutations, and also shows somatic insertions (Kim et al. 1990, 1994; Kim and Belyaeva 1991).

\section{Conclusions}

Kim et al. (1994) have performed experiments in which crude embryo or pupal extracts derived from the MSN1 strain (an SS strain carrying a gypsy element derived from MS) were microinjected into embryos or fed to larvae of SS strains, respectively. Using the $o v O^{D 1}$ reversion assay, they provided evidence that the MSN1 strain extracts contained a trans-acting factor that stimulated gypsy insertion. Although these results strongly support the notion that gypsy is an infectious retrovirus, they failed to prove it. In the experiments by Kim et al., as well as in our $\mathrm{OVO}^{D 1}$ reversion experiment, it is formally possible that what is being transmitted to the progeny is not a viral particle but a positive activator of transposition. Although the recipient SS strain used in these experiments lacks active gypsy copies, the $o v O^{D 1}$ strain to which it was crossed may well contain active gypsy elements, and these experiments cannot rule out the possibility that these $o v o^{D 1}$ strain-derived elements were activated in trans by the material from the MSN1 for flam) donor strains. However, in our second feeding experiment, in which only the inactive SS strain was used, we have ruled out any role of the gypsy elements in the ovo ${ }^{D 1}$ strain. Final proof of gypsy infectivity will require the mobilization of genetically marked gypsy elements.

Could gypsy be both a retrotransposon and a retrovirus? The fact that the flam mutation specifically affects ORF3 expression raises the possibility that gypsy is a facultative retrovirus, expressing an infectious form only under special circumstances, and that under separate conditions it might transpose by an intracellular pathway that requires only gag and pol. However, at this point this must remain only a speculation, for the existing data are equally consistent with all gypsy "transposition" being mediated entirely by an intercellular infection process. The finding that gypsy is probably an infectious retrovirus of Drosophila raises many new questions that will be the subject of future investigations. The availability of a genetically tractable system with infectious retroviruses will be especially useful for tackling such problems. What is the receptor for the ORF3 protein, and what is the route by which virus particles enter the larva, and eventually the germ line of the progeny? What is the host range of the gypsy virus? Its presence in sibling species of $D$. melanogaster (Mizrokhi and Mazo 1990) suggests that at least the genus Drosophila will be susceptible. The development of marked gypsy elements bearing phenotypic markers will be a powerful tool for answering such questions, and also 
should allow the development of a new microinjectionindependent germ-line tranformation strategy for Drosophila.

\section{Materials and methods}

Strains and genetic crosses

The strains MG\#3 (flam/FM3) (N. Prud'homme, M. Gans, M. Masson, C. Terzian, and A. Bucheton, in prep.), ovo ${ }^{D 1}{ }_{V}$ (MévelNinio et al. 1989), and SS (w flam) (Kim et al. 1990) were provided by A. Bucheton (CNRS, Gifsur Yvette, France). These strains are maintained on standard Drosophila medium; all genetic experiments were carried out at $25^{\circ} \mathrm{C}$.

\section{Generation of $m A b s$}

The mAbs 7B3 and 8E7 were generated by using the following protocol. The 1612 bp StyI-XhoI gypsy fragment was inserted into pATH3 (Koerner et al. 1991) for TrpE-ORF3 fusion protein production. Cells containing the construction were induced with $\beta$-indole acrylic acid and an $89-\mathrm{kD}$ TrpE-ORF3 fusion protein was isolated. BALB/c mice (5-6 months old) were immunized with the fusion protein. Mice received an initial injection of $100 \mathrm{mg}$ of protein emulsified 1:1 with Freund's complete adjuvant. After 2 weeks, the mice were given three boosts of 100 $\mathrm{mg}$ of protein in Freund's incomplete adjuvant at 2-week intervals. Six days after the final boost, serum samples were tested by immunoblotting. Mice giving good serum responses were boosted with $100 \mathrm{mg}$ of protein with Freund's incomplete adjuvant 4 days before the fusion. Spleen cells were fused in the presence of PEG 4000 (GIBCO) to sp2/0 myeloma cells, using standard protocols (Harlow and Lane 1988). Hybridoma supernatants were screened 1-2 weeks later on immunoblot strips containing either TrpE protein or the fusion protein. Antibodies $7 \mathrm{~B} 3$ and $8 \mathrm{E} 7$ react only with the fusion protein. Positive preclones were cloned by limiting dilution. Ascites were produced as described (Harlow and Lane 1988).

\section{Immunoblotting}

Ovaries from 3- to 5-day-old females flies were isolated in buffer $[0.1 \mathrm{M} \mathrm{NaCl}, 0.01 \mathrm{M}$ Tris- $\mathrm{HCl}(\mathrm{pH}$ 7.4), $0.001 \mathrm{M}$ EDTA, $0.001 \mathrm{M}$ PMSF] and transferred into SPS lysis buffer [2.5\% SDS, $60 \mathrm{~mm}$ Tris- $\mathrm{HCl}$ (pH 7.4), $0.005 \%$ bromophenol blue, $10 \%$ glyceroll for homogenization. After homogenization, proteins were boiled for $10 \mathrm{~min}$, spun for $5 \mathrm{~min}$, and stored at $-20^{\circ} \mathrm{C}$. Gradient fractions $(100 \mu l)$ were precipitated by $10 \%$ TCA and resuspended in sample buffer. Samples for immunoblotting were prepared as above.

Proteins were run on $12 \%$ or $15 \%$ polyacrylamide gels and electroblotted onto nitrocellulose. Immunoblots were blocked for $0.5-1 \mathrm{hr}$ with $5 \%$ powdered milk in PBST [ $150 \mathrm{mM} \mathrm{NaCl}, 10$ mM phosphate ( $\mathrm{pH} 7.0), 0.3 \%$ Tween 20 ]. Primary antibodies (hybridoma culture supernatant diluted $1: 10$ ) were added in $1 \%$ milk in PBST and incubated for $1.5 \mathrm{hr}$ at room temperature. Blots were washed for $1 \mathrm{hr}$ in PBST and incubated with peroxidase-conjugated secondary antibodies (Sigma) for $1.5 \mathrm{hr}$ in PBST at a dilution of 1:10,000. The washing procedure was repeated, and the blots were subjected to ECL Western blotting protocols (Amersham).

\section{Homogenization of flies and sucrose density gradient} analysis

Two grams of 3- to 5-day-old female flies were homogenized in buffer $[0.1 \mathrm{M} \mathrm{NaCl}, 0.01 \mathrm{M}$ Tris- $\mathrm{HCl}(\mathrm{pH} 7.4), 0.001 \mathrm{M}$ EDTA, $0.001 \mathrm{M}$ PMSF] using a Dounce homogenizer at $4^{\circ} \mathrm{C}$. This homogenate was spun down at $10 \mathrm{~K}$ rpm for $10 \mathrm{~min}$. The supernatant was transferred to a new $15-\mathrm{ml}$ tube and spun down again at $10 \mathrm{~K} \mathrm{rpm}$ for $5 \mathrm{~min}$ to get rid of debris. The total protein content of flam and control extracts was assayed by $\mathrm{OD}_{280}$ and found to be identical. The final supernatants $(\sim 4.5 \mathrm{ml})$ were loaded onto $20-70 \%$ linear sucrose gradients prepared and fractionated as described (Braiterman et al. 1994). In gradient experiment 1 , no protease inhibitor cocktails were added, whereas in experiment 2, $1 \times \mathrm{PIC} 1$ and PIC2 were added to the extracts as described (Braiterman et al. 1994). Five-microliter aliquots of the fractions were used for exogenous and endogenous RT assays, and 100- $\mu$ l aliquots were precipitated by TCA and used for immunoblot analysis.

\section{RT assays}

Exogenous RT assays using a poly $(\mathrm{A})$-oligo(dT) primer template were performed in $42 \mathrm{~mm}$ Tris- $\mathrm{HCl}(\mathrm{pH} 8.2), 16.7 \mathrm{mM}$ DTT, 50 $\mathrm{mM} \mathrm{NaCl}, 5 \mathrm{~mm} \mathrm{MgCl} 2,0.5 \mathrm{~mm} \mathrm{MnCl} 2,0.042 \%$ NP-40, $8.3 \mu \mathrm{M}$ TTP, $4.17 \mu \mathrm{g} / \mathrm{ml}$ of oligo(dT), and $8.33 \mu \mathrm{g} / \mathrm{ml}$ of poly(A). $\left[\alpha-{ }^{32}\right.$ P]TTP $(0.25 \mu \mathrm{Ci})$ was added per $25 \mu$ l of reaction cocktail and $5 \mu \mathrm{l}$ of fraction, and incubated at room temperature for $1 \mathrm{hr}$. Incorporation was assayed as described (Goff et al. 1981). The washed DEAE paper was analyzed directly with ImageQuant software using a Molecular Dynamics PhosphorImager. The endogenous RT reaction uses internal primer templates; it was performed in an assay cocktail containing $50 \mathrm{~mm}$ Tris- $\mathrm{HCl} \mathrm{lpH}$ 8), $20 \mathrm{~mm}$ DTT, $60 \mathrm{~mm} \mathrm{NaCl}, 6 \mathrm{~mm} \mathrm{MnCl}, 5 \mathrm{~mm} \mathrm{MgCl} 2,0.1 \%$ NP-40, $2 \mathrm{mM}$ dATP, and $600 \mathrm{~mm}$ each of dGTP, dTTP, and dCTP. In $65 \mu \mathrm{l}$ of the cocktail, $5-\mu 1$ aliquots of sucrose gradient fractions and $100 \mu \mathrm{Ci}$ of $\left[\alpha^{-32} \mathrm{P}\right] \mathrm{dATP}$ were added and incubated for $3 \mathrm{hr}$ at room temperature. After incubation, $10 \mathrm{ml}$ of $1 \mathrm{mM}$ dATP was added and incubated for an additional $30 \mathrm{~min}$. The final product was phenol/chloroform-extracted and precipitated in ethanol. DNA purified on a Sephadex G50 column was used as a probe for the DNA blotting analysis.

\section{Electron microscopy}

Aliquots $(100 \mu l)$ of fractions $14-20$ were pooled together and run on $20-70 \%$ step sucrose gradients to concentrate the virus particles. Centrifugation was for $1.5 \mathrm{hr}$ at $25,000 \mathrm{rpm}$ at $4^{\circ} \mathrm{C}$ in a Beckman SW28 rotor. Thirty microliters of concentrated virus particles were adsorbed to a collodion grid for $5 \mathrm{~min}$ at room temperature. The grids were rinsed on three drops of PBS for 1 min each and then incubated on a drop of a mixture of $7 \mathrm{~B} 3$ and $8 \mathrm{E} 7$ (as ascites fluid at a dilution of 1:200 in PBS) for $30 \mathrm{~min}$ at $37^{\circ} \mathrm{C}$ and then for $30 \mathrm{~min}$ at room temperature. After the primary antibody incubations, the grids were washed on three drops of PBS and incubated on a drop of gold-labeled goat antimouse IgG (Amersham) at a concentration of 1:30. After secondary antibody incubation, the grids were rinsed on two drops of PBS and then on two drops of $\mathrm{H}_{2} \mathrm{O}$. The grids were fixed in $2.5 \%$ glutaraldehyde for $5 \mathrm{~min}$ at room temperature and then rinsed in $\mathrm{H}_{2} \mathrm{O}$ three times for $1 \mathrm{~min}$ each. After washing, the grids were stained negatively in a solution of $1 \%$ uranyl acetate and $0.2 \%$ tylose on two drops for $45 \mathrm{sec}$ each. Electron microscopy was performed on a Zeiss transmission electron microscope (model TEM 10A).

\section{DNA manipulations}

Genomic DNA was isolated from 20-30 adult flies using the following method. Flies were homogenized in $400 \mu \mathrm{l}$ of buffer 
$[0.1 \mathrm{M}$ Tris- $\mathrm{HCl}$ (pH 9.0), 0.1 м EDTA, $1 \%$ SDS, $1 \%$ DEPC] with a plastic rod in an Eppendorf tube. This homogenate was incubated for $30 \mathrm{~min}$ at $70^{\circ} \mathrm{C}$, and then $54 \mathrm{ml}$ of $8 \mathrm{M}$ potassium acetate was added and left on ice for $30 \mathrm{~min}$. After spinning for $15 \mathrm{~min}$ at $4^{\circ} \mathrm{C}$, the supernatant was transferred carefully to a fresh Eppendorf tube. DNA was then precipitated by adding a 0.5-volume of isopropanol at room temperature and spun down for $5 \mathrm{~min}$. The DNA pellet was washed carefully with $70 \%$ ethanol, respun, dried, and resuspended in $30-50 \mathrm{ml}$ of $\mathrm{H}_{2} \mathrm{O}$. About $20 \mathrm{ng}$ of genomic DNA was used as template for PCR. PCR was done as follows: $94^{\circ} \mathrm{C}$ for $1 \mathrm{~min}$ and $20 \mathrm{sec}, 65^{\circ} \mathrm{C}$ for 2 min, and $72^{\circ} \mathrm{C}$ for $3 \mathrm{~min}$ for 40 cycles. Hot Tub polymerase and reaction buffers (Amersham) were used with $200 \mu \mathrm{M}$ dXTPs, 1 $\mu \mathrm{M}$ each primer, and $1 \%$ glycerol included in the reaction.

DNA cycle sequencing using oligonucleotide primer JB715, Taq polymerase, and fluorescent dideoxy terminators was carried out directly on PCR products isolated from agarose gels.

The oligonucleotides used were P1, 5'-CAACATGACCGAGGACGGTCATAAAC-3'; P2, 5'-CTCCCGCTCTGCGGGCTTCTCTTT-3'; P3, 5'-CTTTGCCGAAAATATGCAATG-3'; P4, 5'-CGGCTTTTTCAGCGGCTAACC-3'; and JB715, 5'-TAAAACGGAGGTGGCGG-3'.

For in situ hybridization, biotinylated probes of gypsy and copia DNA were used and hybridizations were performed as described (Lim 1993).

\section{Exposure of larvae to gradient fractions}

For infectivity experiments in which larvae were exposed to particles, particles were concentrated by step gradient centrifugation. Particles were concentrated from fractions $14-18$ by pooling the fractions and pelleting the particles through $20 \mathrm{ml}$ of $20 \%$ sucrose at $25,000 \mathrm{rpm}$ in an SW28 rotor for $90 \mathrm{~min}$ onto a $20-\mathrm{ml} 70 \%$ sucrose cushion. The concentrated particles were collected as a single 400- $\mu$ l interface fraction. For feeding experiments, $25 \mu \mathrm{l}$ of this concentrate or unconcentrated fraction 16 was added to standard fly food by gentle mixing every other day for 10 days.

For the antibody inhibition experiment, the indicated antibodies were purified from ascites on protein $G$ using a mAbTrapGII kit (Pharmacia) before use. Concentrated particles (125 $\mu$ l) were preincubated with antibodies $(90 \mu \mathrm{g})$ overnight at $4^{\circ} \mathrm{C}$ and fed as described above.

\section{Methods for obtaining new lines from feeding experiments}

SS flies were fed sucrose gradient fractions containing particles five times every 2 days. Females emerging from these vials were crossed with $o v O^{D 1} v$ males (for reversion experiments, see Table 2) or to unfed SS males for direct observation of polytene chromosomes of progeny larvae without selection (Tables 3 and 4). The $F_{1}$ female progeny from the former cross were mated to Ore- $R$ males to check their fertility. The $F_{2}$ progeny from this cross were subjected to PCR and in situ hybridization. Individual progeny $\mathrm{F}_{2}$ females were also crossed with FM4 males. Individuals from this cross were mated again with FM4 males to test for lethals in the $O V O^{D 1}$ revertant chromosome (a lethal would produce FM4 males only). These manipulations are diagramed in Figure 8.

\section{Deglycosidation with endoglycosidase $F$}

Ovary protein preparation was made as explained above in Western analysis. These proteins were denatured in denaturing buffer $(0.5 \%$ SDS, $1 \% \beta$-mercaptoethanol) by boiling for $10 \mathrm{~min}$ at $100^{\circ} \mathrm{C}$. This protein extract was spun down, and the super-
In situ hybridization assay

ovo ${ }^{D 1}$ reversion assay

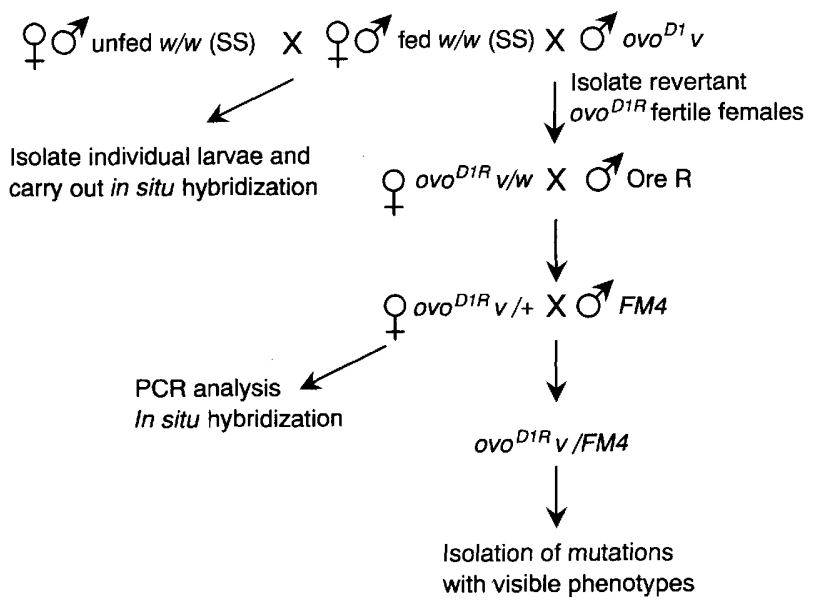

Figure 8. Scheme for in situ hybridization assay and for generating $O V O^{D 1}$ revertant lines. ovo ${ }^{D I R}$ indicates $O V o^{D 1}$ revertant.

natant was taken to a new tube. After adding deglycosidation reaction buffer [ $50 \mathrm{~mm} \mathrm{Na}$ phosphate ( $\mathrm{pH} 7.5), 1 \% \mathrm{NP} 40], 10$ units of PNGase $\mathrm{F}$ (peptide/N-glycosidase $\mathrm{F}$; New England $\mathrm{Bi}$ olabs) enzyme was added. Incubation was for $5 \mathrm{hr}$ at $37^{\circ} \mathrm{C}$.

\section{In vitro transcription/translation}

A 1.5-kb DNA fragment, corresponding to the spliced ORF3 mRNA, was amplified using primers 1475 (5'-AGTTAAGTTAGAAAAGCATGTTCACCCTCATGATGTTCATACCCTTG$\left.3^{\prime}\right)$ and 1463 (5'-ACGAAGCAATACATTGTTAGTTGT-3'). These PCR fragments were cloned directly into the TA cloning vector (pCRII, Invitrogen Corp.). The orientation of the insert was determined by restriction enzyme digestion and sequencing. The plasmid pTA-env has gypsy ORF3 under the control of the bacteriophage T7 promoter. Coupled in vitro T7 transcription-translation was done with the TnT-coupled reticulocyte lysate system (Promega) by following their standard protocol. For the production of nonradiolabeled protein, both amino acid mixture (-Met) and amino acid mixture (-Leu) were used in the reaction.

\section{Statistical analyses}

$P$ values were calculated by a contingency table analysis using Statview II (Abacus Concepts). The reported values are continuity-corrected $P$ values.

\section{Acknowledgments}

We are especially grateful to Alain Pélisson, Alexander Kim, Nicole Prud'homme, and Alain Bucheton for generously providing Drosophila strains as well as information about their experiments before publication. We thank Mike Dellannoy for assistance with immunoelectron microscopy. This work was supported by a Human Frontiers Grant to J.D.B. and National Institutes of Health grant GM35463 and American Cancer Society grant DB-7F to V.G.C.

The publication costs of this article were defrayed in part by payment of page charges. This article must therefore be hereby 
marked "advertisement" in accordance with 18 USC section 1734 solely to indicate this fact.

\section{References}

Boeke, J.D. 1988. Retrotransposons. In RNA genetics. Volume II, retroviruses, viroids, and RNA recombination (ed. E. Domingo, J.J. Holland, and P. Ahlquist) pp. 59-103. CRC Press, Boca Raton, FL.

Boeke, J.D. and V.G. Corces. 1989. Transcription and reverse transcription in retrotransposons. Annu. Rev. Microbiol. 43: 403-433.

Braiterman, L.T., G.M. Monokian, D.J. Eichinger, S.L. Merbs, A. Gabriel, and J.D. Boeke. 1994. In-frame linker insertion mutagenesis of yeast transposon Ty1: Phenotypic analysis. Gene 139: 19-26.

Coffin, J.M. 1993. Reverse transcriptase and evolution. In Reverse transcriptase. (ed. S. Goff and A. Skalka) pp. 445-479. Cold Spring Harbor Laboratory Press, Cold Spring Harbor, New York.

Eggleston, W.B., D.M. Johnson-Schlitz, and W.R. Engels. 1988. P-M hybrid dysgenesis does not mobilize other transposable element families in D. melanogaster. Nature 331: 368-371.

Eichinger, D.J. and J.D. Boeke. 1988. The DNA intermediate in yeast Tyl element transposition copurifies with virus-like particles: Cell-free Tyl transposition. Cell 54: 955-966.

Engels, W.R. 1989. P elements in Drosophila melanogaster. In Mobile DNA (ed. D.E. Berg and M.M. Howe), pp. 437-484. American Society for Microbiology, Washington, D.C.

Gerasimova, T.I., L.V. Matyuyina, Y.V. Ilyin, and G.P. Georgiev. 1984a. Simultaneous transposition of different mobile elements: Relation to multiple mutagenesis in Drosophila melanogaster. Mol. \& Gen. Genet. 194: 517522.

Gerasimova, T.I., L.J. Mizrokhi, and G.P. Georgiev. 1984b. Transposition bursts in genetically unstable Drosophila melanogaster. Nature 309: 714-716.

Goff, S., P. Traktman, and D. Baltimore. 1981. Isolation and properties of Moloney murine leukemia virus mutants: Use of a rapid assay for release of virion reverse transcriptase. $/$. Virol. 38: 239-248.

Harlow, E. and D. Lane. 1988. Antibodies: A laboratory manual. Cold Spring Harbor Laboratory, Cold Spring Harbor, New York.

Kim, A.I. and E.S. Belyaeva. 1991. Transposition of mobile elements gypsy (mdg4) and hobo in germ-line and somatic cells of a genetically unstable mutator strain of Drosophila me1anogaster. Mol. \& Gen. Genet. 229: 437-444.

Kim, A.I., E.S. Belyaeva, and M.M. Aslanian. 1990. Autonomous transposition of gypsy mobile elements and genetic instability in Drosophila melanogaster. Mol. \& Gen. Genet. 224: 303-308.

Kim, A.I., C. Terzian, P. Santamaria, A. Pélisson, N. Prud'homme, and A. Bucheton. 1994. Retroviruses in invertebrates: The gypsy retrotransposon is apparently an infectious retrovirus of Drosophila melanogaster. Proc. Natl. Acad. Sci. 91: 1285-1289.

Koerner, T.J., J.E. Hill, A.M. Myers, and A. Tzagoloff. 1991. High expression vectors with multiple cloning sites for construction of trpE fusion genes: pATH vectors. Methods Enzymol. 33: 477-490.

Kuhn, D. 1970. Another case of mass mutation. Drosophila Inf. Serv. 45: 127.

Lewis, A.P. and J.F.Y. Brookfield. 1987. Movement of Drosophila melanogaster transposable elements other than P ele- ments in a P-M hybrid dysgenic cross. Mol. \& Gen. Genet. 208: 506-510.

Lim, J.K. 1980. Site-specific intrachromosomal rearrangements in Drosophila melanogaster: Cytogenetic evidence for transposable elements. Cold Spring Harbor Symp. Quant. Biol. 45: 553-560.

- 1993. In situ hybridization with biotinylated DNA. Drosophila Inf. Serv. 72: 73-77.

Lim, J.K., M.J. Simmons, J.D. Raymond, N.M. Cox, R.F. Doll, and T.P. Culbert. 1983. Homologue destabilization by a putative transposable element in Drosophila melanogaster. Proc. Natl. Acad. Sci. 80: 6624-6627.

Marck, C. 1988. "DNA Strider": A "C" program for the fast analysis of DNA and protein sequences on the Apple Macintosh family of computers. Nucleic Acids Res. 16: 18291836.

Marlor, R.L., S.M. Parkhurst, and V.G. Corces. 1986. The Drosophila melanogaster gypsy transposable element encodes putative gene products homologous to retroviral proteins. Mol. Cell. Biol. 6: 1129-1134.

McEntee, K. and V. Bradshaw. 1988. Effects of DNA damage on transcription and transposition of Ty retrotransposons in yeast. In Banbury Report 30. Eukaryotic transposable elements as mutagenic agents (ed. M.E. Lambert, J.F. McDonald, and I.B. Weinstein), pp. 245-253, Cold Spring Harbor Laboratory, Cold Spring Harbor, New York.

Mével-Ninio, M., C.M. Mariol, and M. Gans. 1989. Mobilization of the gypsy and copia retrotransposon in Drosophila melanogaster induces reversion of the $\mathrm{OvO}^{D}$ dominant female-sterile mutations: Molecular analysis of revertant alleles. $E M B O$ /. 8: 1549-1558.

Mével-Ninio, M., R. Terracol, and F.C. Kafatos. 1991. The ovo gene of Drosophila encodes a zinc finger protein required for female germ line development. EMBO J. 10: 2259-2266.

Mizrokhi, L.J. and A.M. Mazo. 1990. Cloning and analysis of the mobile element gypsy from $D$. virilis. Nucleic Acids Res. 19: 913-916.

Pélisson, A., S.U. Song, N. Prud'homme, P. Smith, A. Bucheton, and V.G. Corces. 1994. gypsy transposition correlates with the production of a retroviral envelope-like protein under the tissue-specific control of the Drosophila flamenco gene. $E M B O$ \%. (in press).

Rolfe, M., A. Spanos, and G. Banks. 1986. Induction of yeast Ty element transcription by ultraviolet light. Nature 319: 339340.

Strand, D.J. and J.F. McDonald. 1985. copia is transcriptionally responsive to environmental stress. Nucleic Acids Res. 13: $4401-4410$.

Syomin, B.V., V. Konstantin, K.V. Kandror, A.B. Semakin, V.L. Tsuprun, and A.S. Stepanov. 1993. Presence of the gypsy (mdg4) retrotransposon in extracellular virus-like particles. FEBS Lett. 323: 285-288.

Tanda, S., J.L. Mullor, and V.G. Corces. 1994. The Drosophila tom retrotransposon encodes an envelope protein. Mol. Cell. Biol. 14: 5392-5401.

Woodruff, R.C., J.L. Blount, and J.N. Thompson Jr. 1987. Hybrid dysgenesis in $D$. melanogaster is not a general release mechanism for DNA transpositions. Science 237: 1206-1208. 


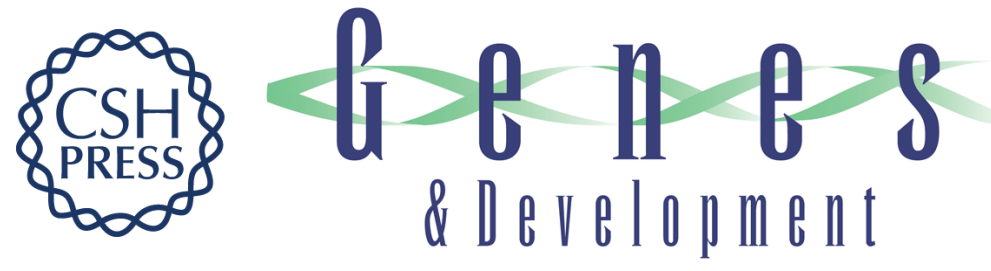

\section{An env-like protein encoded by a Drosophila retroelement: evidence that gypsy is an infectious retrovirus.}

S U Song, T Gerasimova, M Kurkulos, et al.

Genes Dev. 1994, 8:

Access the most recent version at doi:10.1101/gad.8.17.2046

References This article cites 26 articles, 6 of which can be accessed free at:

http://genesdev.cshlp.org/content/8/17/2046.full.html\#ref-list-1

License

Email Alerting

Service

Receive free email alerts when new articles cite this article - sign up in the box at the top right corner of the article or click here.

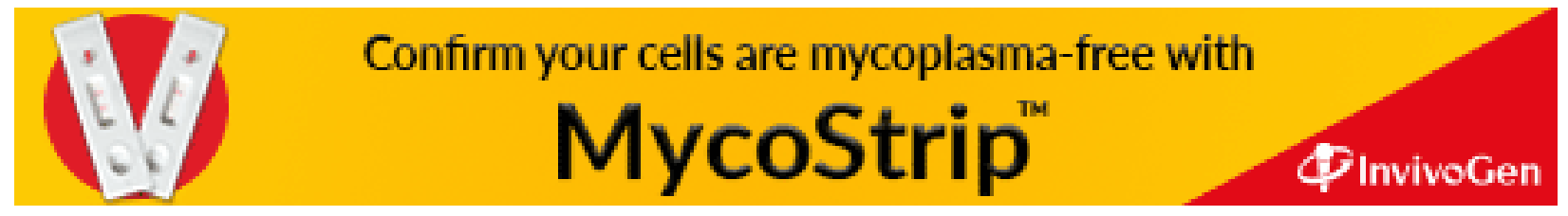

